\title{
Microbial-silica interactions in Icelandic hot spring sinter: possible analogues for some Precambrian siliceous stromatolites
}

\author{
KURT O. KONHAUSER*, VERNON R. PHOENIX*, SIMON H. BOTTRELL*, \\ DAVID G. ADAMS $\uparrow$ and IAN M. HEAD $\ddagger$ \\ ${ }^{*}$ School of Earth Sciences, University of Leeds, Leeds, LS2 9JT, UK \\ (E-mail: k.konhauser@earth.leeds.ac.uk) \\ $\dagger$ Division of Microbiology, School of Biochemistry and Molecular Biology, University of Leeds, \\ Leeds, LS2 9JT, UK \\ $\ddagger$ Fossil Fuels and Environmental Geochemistry Postgraduate Institute, Drummond Building, \\ University of Newcastle, Newcastle upon Tyne, NE1 7RU, UK
}

\begin{abstract}
Silicified deposits, such as sinters, occur in several modern geothermal environments, but the mechanisms of silicification (and crucially the role of microorganisms in their construction) are still largely unresolved. Detailed examination of siliceous sinter, in particular sections of microstromatolites growing at the Krisuvik hot spring, Iceland, reveals that biomineralization contributes a major component to the overall structure, with approximately half the sinter thickness attributed to silicified microorganisms. Almost all microorganisms observed under the scanning electron microscope (SEM) are mineralized, with epicellular silica ranging in thickness from $<5 \mu \mathrm{m}$ coatings on individual cells, to regions where entire colonies are cemented together in an amorphous silica matrix tens of micrometres thick. Within the overall profile, there appears to be two very distinct types of laminae that alternate repeatedly throughout the microstromatolite: 'microbial' layers are predominantly consisting of filamentous, intact, vertically aligned, biomineralized cyanobacteria, identified as Calothrix and Fischerella sp.; and weakly laminated silica layers which appear to be devoid of any microbial component. The microbial layers commonly have a sharply defined base, overlying the weakly laminated silica, and a gradational upper surface merging into the weakly laminated silica. These cyclic laminations are probably explained by variations in microbial activity. Active growth during spring/ summer allows the microorganisms to keep pace with silicification, with the cell surfaces facilitating silicification, while during their natural slow growth phase in the dark autumn/winter months silicification exceeds the bacteria's ability to compensate (i.e. grow upwards). At this stage, the microbial colony is probably not essential to microstromatolite formation, with silicification presumably occurring abiogenically. When conditions once again become favourable for growth, recolonization of the solid silica surface by free-living bacteria occurs: cell motility is not responsible for the laminations. We have also observed that microbial populations within the microstromatolite, some several $\mathrm{mm}$ in depth, appear viable, i.e. they still have their pigmentation, the trichomes are not collapsed, cell walls are unbroken, cytoplasm is still present and they proved culturable. This suggests that the bulk of silicification occurred rapidly, probably while the cells were still alive. Surprisingly, however, measurements of light transmittance through sections of the microstromatolite revealed that photosynthetically active light (PAL) only transmitted through the uppermost $2 \mathrm{~mm}$. Therefore the 'deeper' microbial
\end{abstract}


populations must have either: (i) altered their metabolic pathways; (ii) become metabolically inactive; or (iii) the deeper populations may be dominated by different microbial assemblages from that of the surface. From these collective observations, it now seems unequivocal that microstromatolite formation is intimately linked to microbial activity and that the sinter fabric results from a combination of biomineralization, cell growth and recolonization. Furthermore, the similarities in morphology and microbial component to some Precambrian stromatolites, preserved in primary chert, suggests that we may be witnessing contemporaneous biomineralization processes and growth patterns analogous to those of the early Earth.

Keywords Cyanobacteria, hot spring sinter, Iceland, microstromatolite, silica biomineralization.

\section{INTRODUCTION}

Finely laminated siliceous sinters are built up from heterogeneously nucleated amorphous silica masses that precipitate below life's upper temperature limit from hydrothermal solutions supersaturated with respect to all silica polymorphs (Cady \& Farmer, 1996; Jones \& Renault, 1996). The close association of microorganisms with these deposits has been reported from a variety of hot springs, including Yellowstone National Park, USA (Walter et al., 1972; Walter, 1976a; Ferris et al., 1986; Cady \& Farmer, 1996; Hinman \& Lindstrom, 1996); Lake Bogoria, Kenya Rift (Jones \& Renault, 1996; Renault et al., 1998); El Tatio, Chile (Jones \& Renault, 1997); Geysir and Krisuvik, Iceland (Schultze-Lam et al., 1995; Konhauser \& Ferris, 1996; Konhauser et al., 1999); and several sites in the Taupo Volcanic Zone, New Zealand (Renault et al., 1996; Jones et al., 1997a,b, 1998, 1999). The role of microorganisms in geothermal silica precipitation had generally been considered a passive process (Walter et al., 1972), in that rapid cooling to ambient temperatures, evaporation and/or steam loss, mixing and changes in $\mathrm{pH}$ of the hydrothermal waters after discharge could all induce silicification onto growing cells (Fournier, 1985). In fact, Walter (1976b) defined geyserite to mean an abiogenic, microbanded, opaline silica sinter deposit formed in the proximity of spring vents and fissures at temperatures in excess of $73{ }^{\circ} \mathrm{C}$, temperatures too high to support abundant microbial activity. However, several recent studies using transmission electron microscopy (TEM) and scanning electron microscopy (SEM) have shown that microorganisms provide favourable nucleation sites for silicification over a range of temperatures
(Ferris et al., 1986; Schultze-Lam et al., 1995; Cady \& Farmer, 1996; Konhauser \& Ferris, 1996; Renault et al., 1996, 1998; Jones \& Renault, 1997; Jones et al., 1997a,b, 1998, 1999; Konhauser et al., 1999; Phoenix et al., 1999, 2000). Biogenic silicification has even been shown to occur in thermal springs in the Kenya Rift where water temperatures reach above $90{ }^{\circ} \mathrm{C}$, temperatures too high to support cyanobacteria and most bacteria. Instead, hyperthermophilic bacteria were shown to survive in this extreme environment, preferentially fixing silica onto secreted microbial mucus (Jones \& Renault, 1996).

The mineralization associated with microbial cells generally occurs as spheroidal grains (ranging from $100 \mathrm{~s}$ of $\mathrm{nm}$ to $2 \mu \mathrm{m}$ in diameter) both extracellularly, on the sheaths of living cells, and intracellularly, within the cytoplasm, presumably after the cells have lysed. If silicification is sustained, the silica particles invariably coalesce until the individual precipitates are no longer distinguishable: entire colonies can become cemented together in a siliceous matrix several micrometres thick. The timing and rate of silicification relative to death of the microbes governs their preservation as intact cells. When silicification is rapid, both live and recently lysed cells may resist decay, thereby retaining intact morphologies (Ferris et al., 1988; Cady \& Farmer, 1996; Konhauser et al., 1999; Phoenix et al., 2000). However, experimental studies have shown that unmineralized cyanobacteria begin to degrade only a few days after death (Bartley, 1996). As a result, the remains of other cells may become progressively obscured, and only the sheath and cell wall of the original organic framework, or some remnants of cytoplasm, may stay recognizable. Eventually only the silicified 
matrix of the original organic framework remains, leaving little evidence of the original microbial filaments.

The above observations indicate that silicification begins when microbial communities are living, and continues for some time after their death. The microorganisms at hot springs appear to facilitate silicification by providing reactive interfaces for silica adsorption, thereby reducing the activation energy barriers to nucleation, and permitting surface chemical interactions that sorb more silica from solution. In this way, the bacterium functions as a reactive interface, or template, for heterogeneous nucleation. Because a sufficient supply of silica is generally available in hot spring effluent (in excess of mineral solubility), continued adsorption results in the surface sites becoming saturated, allowing particle nucleation to take place. After bacteria initiate silica precipitation, continued growth of the silica precipitates presumably occurs autocatalytically and abiogenically, due to the increased surface area generated by the small silica phases. The silica precipitated within the pore spaces between filaments has the same basic motif and morphology as the silica precipitated on the original filaments, supporting the notion that the bacterial filaments merely act as nucleation sites for silicification (Ferris et al., 1986; Schultze-Lam et al., 1995; Jones et al., 1998; Konhauser et al., 1999). Mineral growth favours the initial formation of the amorphous solid phases because they have lower interfacial free energies, and hence faster nucleation rates than more stable crystalline phases (Steefel \& Van Cappellen, 1990).

The silicification of indigenous microflora is often pervasive, and not limited to any particular taxa. The only variation is in the fabric of the siliceous deposits and in the type of constructing microorganisms. For example, at any one sinter deposit several different biofacies can be identified (i.e. geyserite, spicules, columnar and stratiform microstromatolites, oncoids and coccoid microbial mats). Each biofacies type forms under a different hydrodynamic, geochemical and temperature regime, and each is characterized by a unique microbial assemblage (Walter et al., 1972; Walter, 1976a,b; Jones et al., 1997a, 1998; Renault et al., 1998).

A certain degree of rhythmicity also occurs in sinter deposits because these mineralized structures are frequently laminated. In Yellowstone, laminations have been attributed to daily growth patterns between unicellular cyanobacteria, Synechococcus sp. and filamentous, gliding, photo- synthetic bacteria, Chloroflexus sp. (Walter et al., 1972; Doemel \& Brock, 1974, 1977). The upward migration of Chloroflexus sp. at night, in response to low light levels and positive aerotaxis, causes the bacteria to accumulate at the surface, while the following day, rapid growth by Synechococcus sp. results in the repopulation by the cyanobacteria at the mat surface. The laminae that result are 10's of micrometres thick, and comprise of dark laminae, in which filaments are contiguous and lie in the plane of the laminae, and light laminae that consist of nearly vertical filaments (Walter et al., 1972). These microstromatolites, however, also have a seasonal control superimposed on them because they do not grow continuously throughout the year (Hinman \& Lindstrom, 1996). This is particularly evident in the outflow channels of 'Column Spouter', Fairy Creek Meadows in Yellowstone, where silicified mats of Calothrix coriacea form anastomozing terraces in water cooler than $30^{\circ} \mathrm{C}$ (Walter, 1976a). In siliceous microstromatolites from Dragon's Mouth Geyser \& Ohaaki Pool, New Zealand, Jones et al. (1997a; 1998) have described erect, large-diameter filaments, aligned parallel with each other and subperpendicular to the growth surface, alternating with layers in which numerous small-diameter filaments lie parallel to the surface. The cause of the alternating erect and prostrate laminae has been tentatively associated with seasonal changes.

Laminations in carbonate deposits have similarly been ascribed to seasonally controlled differences in the rate of biotic activity. In freshwater tufa and travertine deposits, some laminae, with upright biogenic structures, form as a result of rapid growth in spring and summer, while micritic layers, with flat-lying microbial remains, result from the cessation of growth during autumn/winter (Pentecost \& Riding, 1986; Chafetz et al., 1991). In Hamelin Pool, Western Australia, intertidal stromatolites are seasonally covered by mats of coccoid cyanobacteria. At the peak of the summer season, evaporation causes increased hypersalinity, calcium carbonate precipitation, lithification of the mat and cessation of cyanobacterial growth. Following seasonal lowering of salinity, the cyanobacteria re-colonize the lithified surfaces, beginning another cycle of mat development (Seong-Joo et al., 2000). The laminated fabric results from concurrent microbial growth and sediment precipitation. Commonly, microbial mats contain a consortium of microorganisms which do not grow at the same time or under the same conditions (Monty, 1976). This is 
illustrated in the microbial mats of eastern Andros, Bahamas, where Scytonema sp., a freshwater, terrestrial cyanobacterium grows at the surface in the dry season, whereas Schizothrix sp. is a cyanobacterium more successful during flooded conditions and withstands saline waters. In the salinas at Lanzarote, Spain, filamentous cyanobacteria glide downwards into the microbial mat during the summer, leaving a surface population of coccoid cyanobacteria and diatoms on the surface. In winter, the filamentous cyanobacteria adjust to the lower light intensity and subsequently glide up through the overlying surface populations and sediment to re-establish a new surface mat (Gerdes et al., 1994).

Although the presence of silicified microorganisms in sinter is well documented, there is at this point no clear understanding of the importance of indigenous microflora to the overall silicification process, and crucially the role of microorganisms in microstromatolite construction. In the current study from Krisuvik, Iceland, sections of siliceous microstromatolites were sampled for detailed microscopic analysis to ascertain whether biomineralization is fundamental to its formation. Silica-cyanobacteria interactions are demonstrated to account for a significant fraction of the microstromatolite and the laminated fabric probably results from seasonal interactions between a mixed microbial population and a geothermal environment with high concentrations of soluble silica. As discussed below, these laminations are reminiscent of those observed in some Precambrian stromatolites, suggesting that these hot springs may provide modern-day analogues to the precipitation of a number of siliceous deposits in the geological past.

\section{SITE DESCRIPTION}

The main vent at Krisuvik, Reykjanes Peninsula, Iceland (Fig. 1) consists of a drill hole emanating from a raised platform $\left(\sim 9 \mathrm{~m}^{2}\right)$ built in 1974 . Surrounding the platform is a terraced surface of siliceous sinter extending several metres away from the vent in all directions, and ranging in thickness from a few millimetres to approximately $10 \mathrm{~cm}$ at its thickest extent. There is a slight gradient in sinter thickness, with the thickest sections being those immediately adjacent to the platform where there is relatively constant contact with discharged effluent, and those areas downwind from the vent where aircooled spray is deposited. At present, there is a shallow pool of water $(<1 \mathrm{~cm})$ partially surrounding the vent on two sides which is, in part, bounded by topographically high sinter rims. To the side of the pool a discharge apron serves as the main conduit for the geothermal waters into

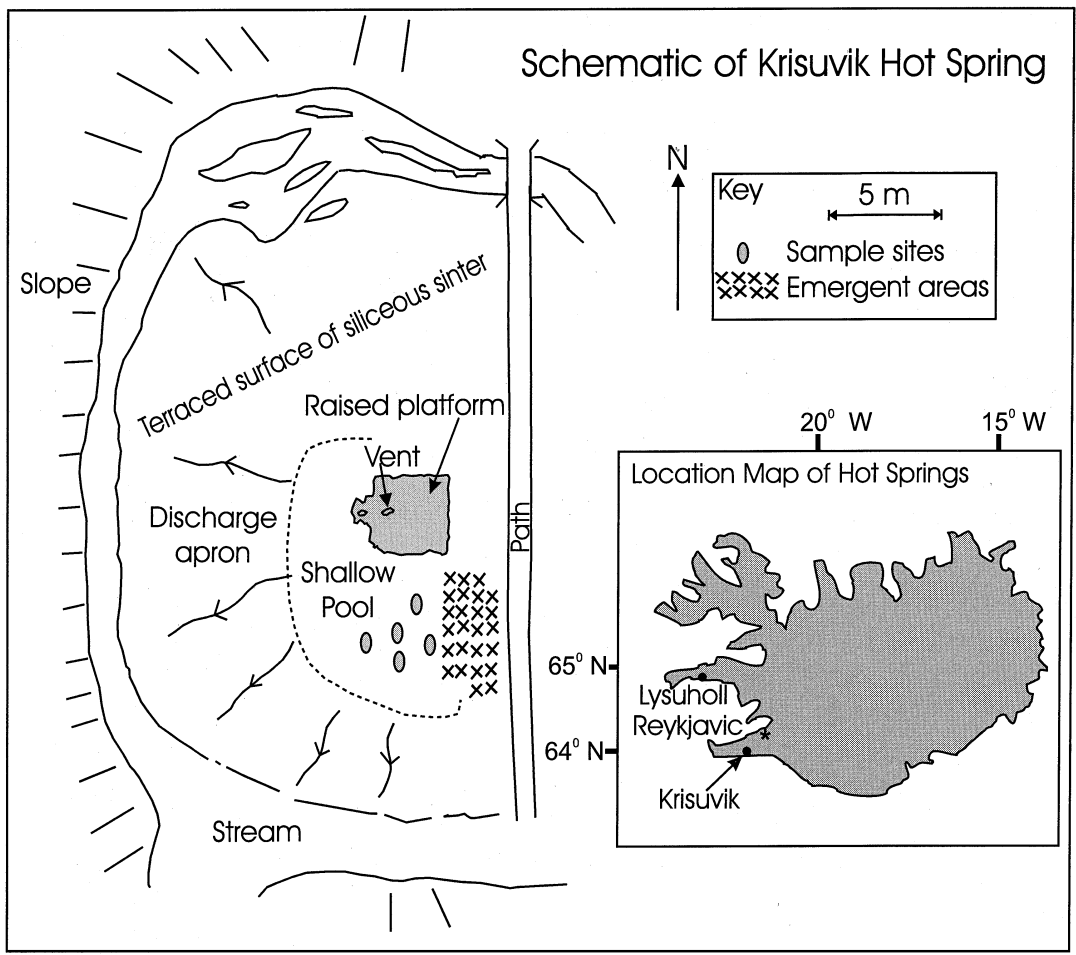

Fig. 1. Location of study areas at Krisuvik and Lýsuhóll, Iceland. Inset shows details of the Krisuvik hot spring and where sinter samples were collected. 
a nearby stream. Those areas now emergent represent topographic highs where effluent used to discharge, but aggradation caused by previous sinter precipitation presumably changed the local hydraulic gradient. Other low volume outflow channels discharge into the same stream.

At the surface of the terrace, in both submerged and emergent areas, there are several dense clusters comprising individual dome- to column-like structures, ranging in size from 1 to $3 \mathrm{~mm}$. The clusters themselves range from approximately $2 \mathrm{~cm}$ to those several tens of centimetres in size. Similar clusters, previously termed microstromatolites, have been identified from Lake Bogoria (Renault et al., 1998); Yellowstone (Walter et al., 1972; Walter, 1976a); and the Taupo Volcanic Zone (Jones et al., 1997a,b; 1998). Their maximum relief is governed by the depth of water in which the structures grew, and in general, do not extend much beyond $10 \mathrm{~mm}$ above the water surface. In addition to the microstromatolites, siliceous oncoids are irregularly scattered over the terraced surface. These structures (between 1 and $10 \mathrm{~cm}$ in diameter) are coated grains that form when microorganisms either bind detrital grains or precipitate authigenic minerals onto their surfaces. They usually form in the shallow waters of discharge aprons, where aqueous temperatures are below $65{ }^{\circ} \mathrm{C}$ (Renault et al., 1996; Jones \& Renault, 1997; Jones et al., 1998; 1999). Close examination of the Krisuvik oncoids has shown that some of the cores consist of stromatolitic fragments and volcanic detritus. In areas of direct contact with drainage waters or spray the microstromatolites and oncoids are well indurated and are difficult to prise off the surface. In those areas which have been emergent for some time both structures have become friable and loosely aggregated.

The temperature and $\mathrm{pH}$ of the effluent vary according to the site of discharge. The water in the shallow pool is characterized by moderate temperatures within the range of $30-40{ }^{\circ} \mathrm{C}$, and $\mathrm{pH}$ between 8.0 and 8.8 . These waters probably reflect the bulk groundwaters that have been buffered by silicate weathering deep underground. Where there has been a separation of gas and liquid phases, sulphidic steam (condensate $\mathrm{pH}=6.4$ ) is released and emerges around the sides of the vent. The dominant ions in the bulk fluids consist of $\mathrm{SiO}_{2}\left(314 \mu \mathrm{g} \mathrm{mL} \mathrm{L}^{-1}\right) ; \mathrm{K}(23 \cdot 2 \mu \mathrm{g}$ $\left.\mathrm{mL}^{-1}\right)$; Ca $\left(8 \cdot 1 \mu \mathrm{g} \mathrm{m}^{-1}\right), \mathrm{Mg}\left(0 \cdot 47 \mu \mathrm{gL}^{-1}\right), \mathrm{Fe}$ $\left(0 \cdot 05 \mu \mathrm{g} \mathrm{mL}^{-1}\right)$ and $\mathrm{SO}_{4}^{2-}\left(72 \cdot 5 \mu \mathrm{g} \mathrm{mL}^{-1}\right)$.

\section{METHODOLOGY}

Microstromatolites were collected (in July, 1998) from the shallow pool of water that partially surrounds the main vent. Sections $(<5 \mathrm{~cm}$ wide $)$ were prised from the surface with a scalpel, returned to Leeds for examination and made into thin sections for light microscopy and polished blocks for SEM. The light microscopy was performed using a Leitz Wetzlar petrological light microscope fitted with a Wild Photoautomat MPS55 camera unit. Polished blocks were firstly carbon coated and then analysed in backscatter electron mode (BSE) using a Camscan SEM operating at $20 \mathrm{kV}$, equipped with a Link analytical Energy Dispersive X-ray Spectroscopic detector (EDS) for qualitative determination of mineral chemistry.

To estimate field silicification rates, $1 \cdot 0-\mathrm{mm}$ thick glass microscope slides were placed at several sites in the outflow apron of the Krisuvik hot spring, at approximately $4 \mathrm{~m}$ from the vent. The water depth was on the order of $1 \mathrm{~cm}$ and the slides were thus totally submerged in effluent. After 4 days the slides were retrieved, air dried to prevent the precipitate from washing from the slide surface and stored in polythene sample bags. On return to Leeds the slides were gold coated and analysed under the SEM at $6 \mathrm{kV}$.

Thin sections of siliceous microstromatolites were also used to determine light transmittance through the biogenic structure. First, wafers of the Krisuvik microstromatolites were prepared by thin sectioning one set of samples into $0 \cdot 2$, $0 \cdot 5,0.75,1 \cdot 0,1.5$ and $2 \mathrm{~mm}$ slices. Another two sets of microstromatolite samples were sectioned into $0.75,1 \cdot 0,2.0$ and $3.0 \mathrm{~mm}$ slices. Iron is a common component of hot spring sinter, which in abundance gives the sinter a brown colouration, potentially reducing its ability to transmit photosynthetically active light (PAL, 400$700 \mathrm{~nm}$; Vincent \& Roy, 1993). The Krisuvik sinter contained low levels of iron (around $300 \mu \mathrm{g} \mathrm{g}^{-1}$ ), and therefore has potentially high PAL transmission properties. To compare this with other Fe-enriched sinters, sinter from the Lýsuhóll hot spring site on the Snafellsnes Peninsula (containing approximately $7000 \mu \mathrm{g}$ $\mathrm{g}^{-1} \mathrm{Fe}$ ) was also sectioned into slices of $0 \cdot 15$, 0.2 and $0.25 \mathrm{~mm}$ thickness. All wafers were approximately $15 \times 35 \mathrm{~mm}$ in area. To ensure that light transmittance was measured through the same sized area of microstromatolite sample each time, a $10 \times 20 \mathrm{~mm}$ window was cut into 
cardboard, and the relevant wafer was fixed in position over the window. The transmittance of PAL through the sinter window was measured using a Macam Q102 Radiometer and was measured at $150 \mathrm{~mm}$ from an 18 watt fluorescent lamp; the reading was taken when it had settled to a constant value. For each section, three readings were taken and the average and standard deviation determined.

The filamentous cyanobacteria Calothrix sp. and Fischerella sp. (Mastigocladus sp.) were isolated from the upper surface of the microstromatolite and cultured aerobically in BG11 liquid medium (Rippka et al., 1979), at $30^{\circ} \mathrm{C}$ in conical flasks with shaking at 100 r.p.m. and an average light irradience of $24 \mu \mathrm{mol} \mathrm{m}{ }^{-2} \mathrm{~s}^{-1}$. Filaments were also cultured on $1.5 \%(\mathrm{w} / \mathrm{v})$ agar plates containing BG11 medium lacking nitrate, at $30{ }^{\circ} \mathrm{C}$ and an average light irradience of $24 \mu \mathrm{mol} \mathrm{m}{ }^{-2} \mathrm{~s}^{-1}$, until an even growth across the plates was achieved. Stock cultures were maintained in either the same liquid or agar medium at room temperature and at a low average irradience of approximately $3 \mu \mathrm{mol} \mathrm{m} \mathrm{m}^{-2} \mathrm{~s}^{-1}$.

\section{OBSERVATIONS}

The microstromatolitic sample described below consists of a 7-mm section, with a thick, wedgeshaped feature; several dark, attenuated patches ( $\sim 100 \mu \mathrm{m}$ thick); and numerous poorly defined, dark-coloured horizons, or laminae (Fig. 2). The overall structure appears domical to columnar in cross-section, with a rounded, convex-upwards surface approximately $2.5 \mathrm{~mm}$ thick. The structures also show no orientation related to flow, with most having nearly circular transverse sections. The laminae are generally planar at the bottom of the column, but near the top they commonly bend down abruptly near the column margins, forming a wall. Growth also occurs between some of the columns so that the laminae continue through to adjacent columns. Similar dome- to column-structures exist to either side of the imaged section.

The base of the microstromatolite sample is composed of a layer of allochthonous material containing pyrite, pyroxenes, feldspars and quartz, partly bound by a later silica cement (see A in Fig. 2). These minerals are residues depos-

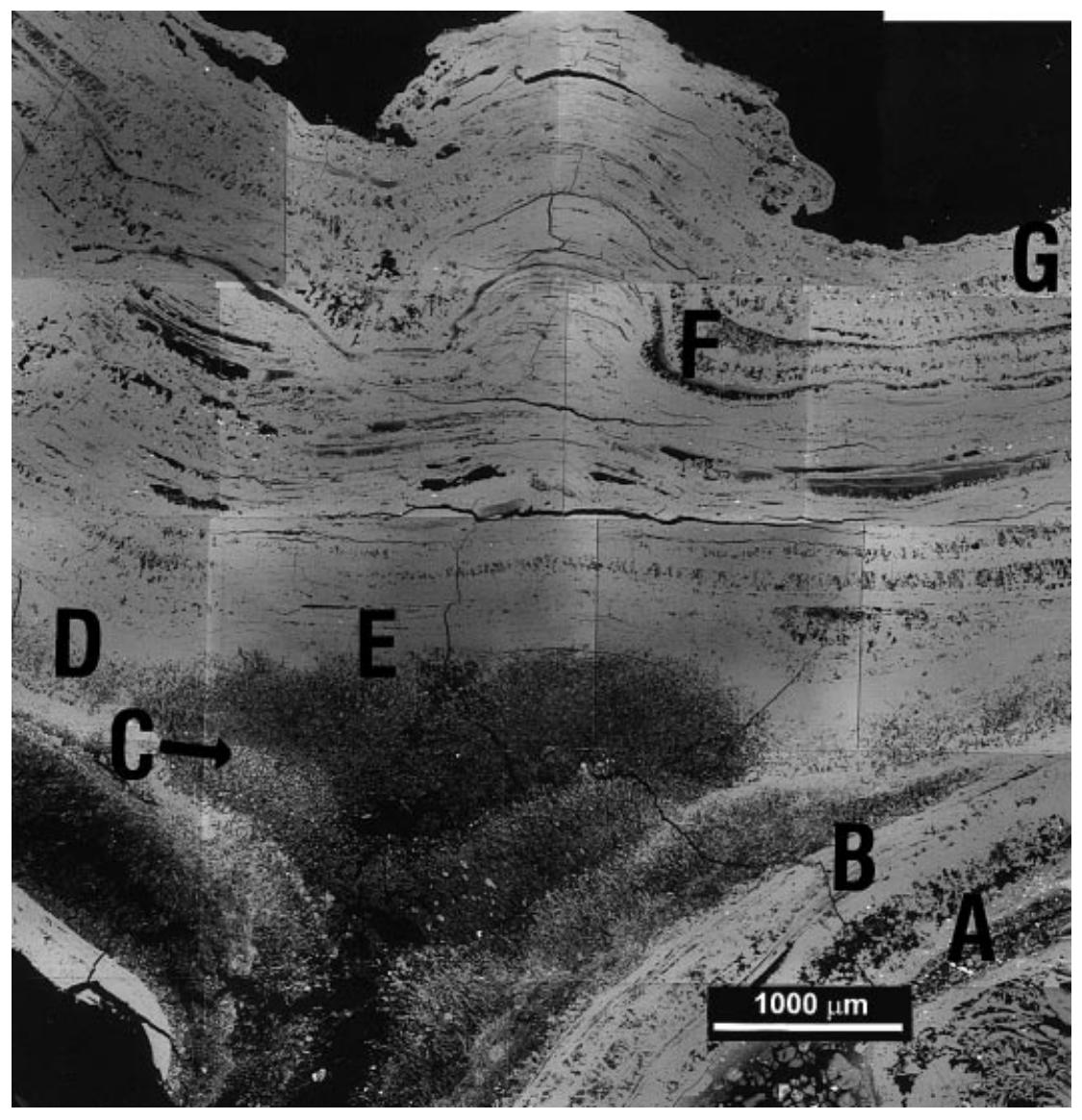

Fig. 2. Scanning electron micrograph (SEM) of an approximately $7 \mathrm{~mm}$ section of siliceous microstromatolite collected from Krisuvik, Iceland. (A) Allochthonous material derived from blasting of drill hole; (B) sharp contact between base of the microbial colony within the wedge with the underlying silica layer; (C) gradient of biomineralization within microbial wedge, from heavily encrusted colonies to the light silicification of individual cells; (D) top of the wedge where the microbial colony spreads laterally into a diffuse layer; (E) top of the colony where microorganisms gradationally project into overlying silica layer; (F) dense microbial layers growing in depressions on the microstromatolite; (G) topmost section of the microstromatolite where a microbial layer is overlain by a thin (10's of micrometres thick) layer of amorphous silica. 
ited from drilling of the borehole 25 years earlier. The allochthonous material is overlain by a weakly laminated silica layer approximately $500 \mathrm{~nm}-1 \mathrm{~mm}$ thick (see B in Fig. 2). Detailed examination of this silica layer revealed a porous texture with a series of cavities that are elongated along the apparent laminations (Fig. 3). Whether the laminations are due to subtle grain size or compositional variations is undetermined. Above this there is a large, dark-coloured wedge (approximately $3 \mathrm{~mm}$ thick) consisting of a microbial colony. The base of this microbial colony (see B in Fig. 2) shows that the contact is very sharp (Fig. 3), with no evidence of downward boring. The centre of the colony is directly linked to an underlying fracture, which presumably serves as a conduit for fluids and transported microorganisms.

Examination of the microstromatolite with light microscopy revealed that within the microbial colony the dominant cells consisted of long, uniseriate (one cell thick), unbranching filaments, or trichomes (each many 10's of micrometres in length), with a green-brown colouration. Under the SEM, the trichomes display a preferred vertical orientation, with alignment towards the sediment-water interface (Fig. 4). The trichomes are usually fully articulated, not collapsed and often completely enclosed by sheath material; only at the ends are individual cells occasionally shown protruding through the sheaths. External to the sheath is an observable layer of amorphous silica precipitate (see below). Individual cells comprising the trichomes are on average 5-8 $\mu \mathrm{m}$ in width, oval-to-cylindrically shaped, and they generally appear intact, i.e. the cell walls are unbroken and the cytoplasm is still present (Fig. 5A). This suggests that silicification occurred rapidly, possibly while the cells were still alive, or very shortly after death (Bartley, 1996). Only a few cells show signs of intracellular mineralization. In those instances, the only remaining structures of the cell are their sheaths and wall, and sometimes fragments of their cytoplasm. Commonly the trichomes taper at one apical end and are bulbous at the opposite end; thick-walled heterocysts have been identified in the latter, suggesting that these cells are similar in appearance to species such as Calothrix sp. (Rippka et al., 1979). Other filamentous cells exist in lesser numbers, with some displaying lateral branching characteristic of Fischerella

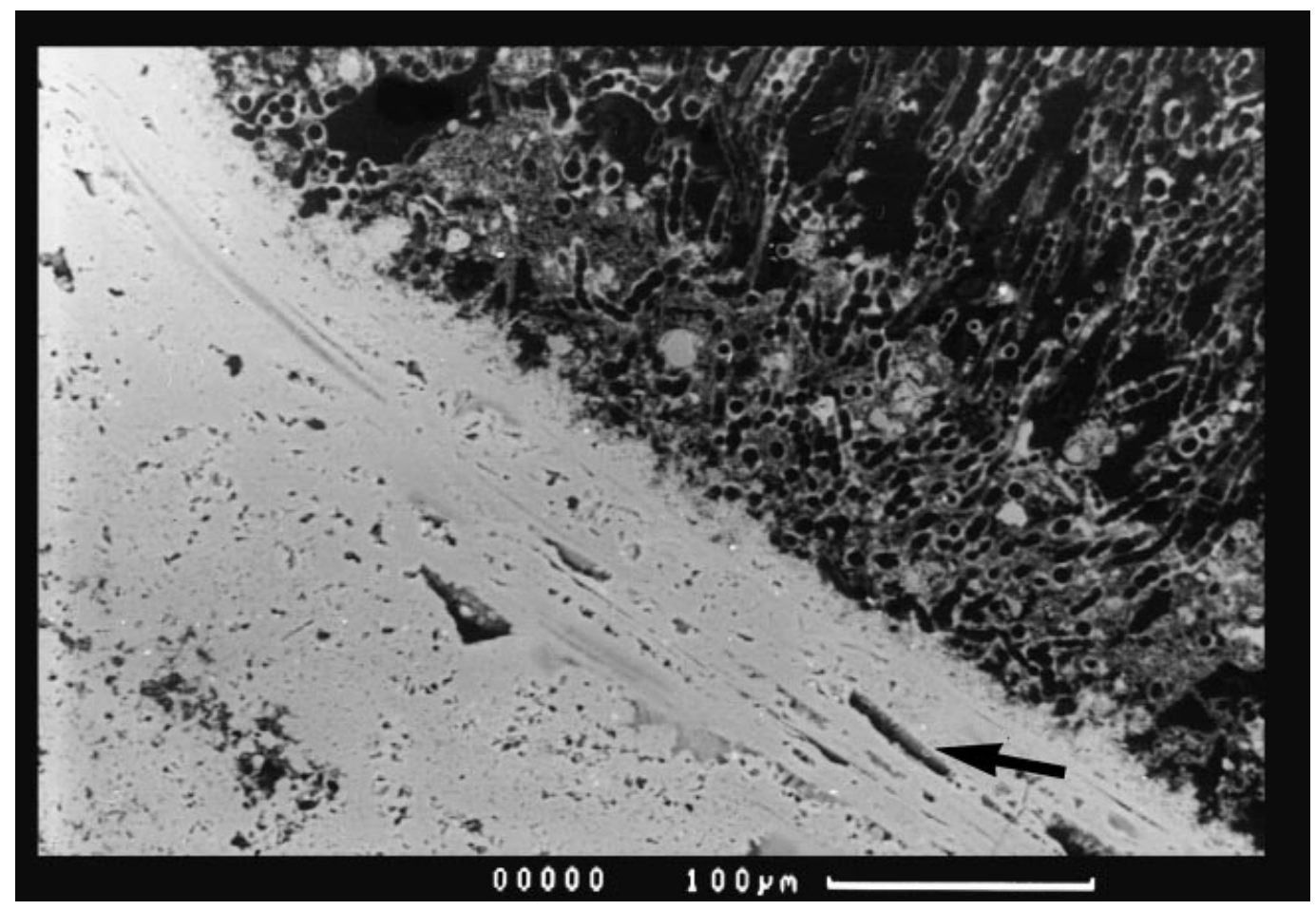

Fig. 3. Close-up SEM image from Fig. $2 B$ of the sharp contact between the weakly laminated, inorganic silica layer (bottom left) and the predominantly filamentous, intact, vertically aligned microbial layer dominated by cyanobacteria (top right). Note the porous texture with a series of cavities in the silica layer (arrow), as well as the lack of downward boring by the microorganisms above.

(C) 2001 International Association of Sedimentologists, Sedimentology, 48, 415-433 


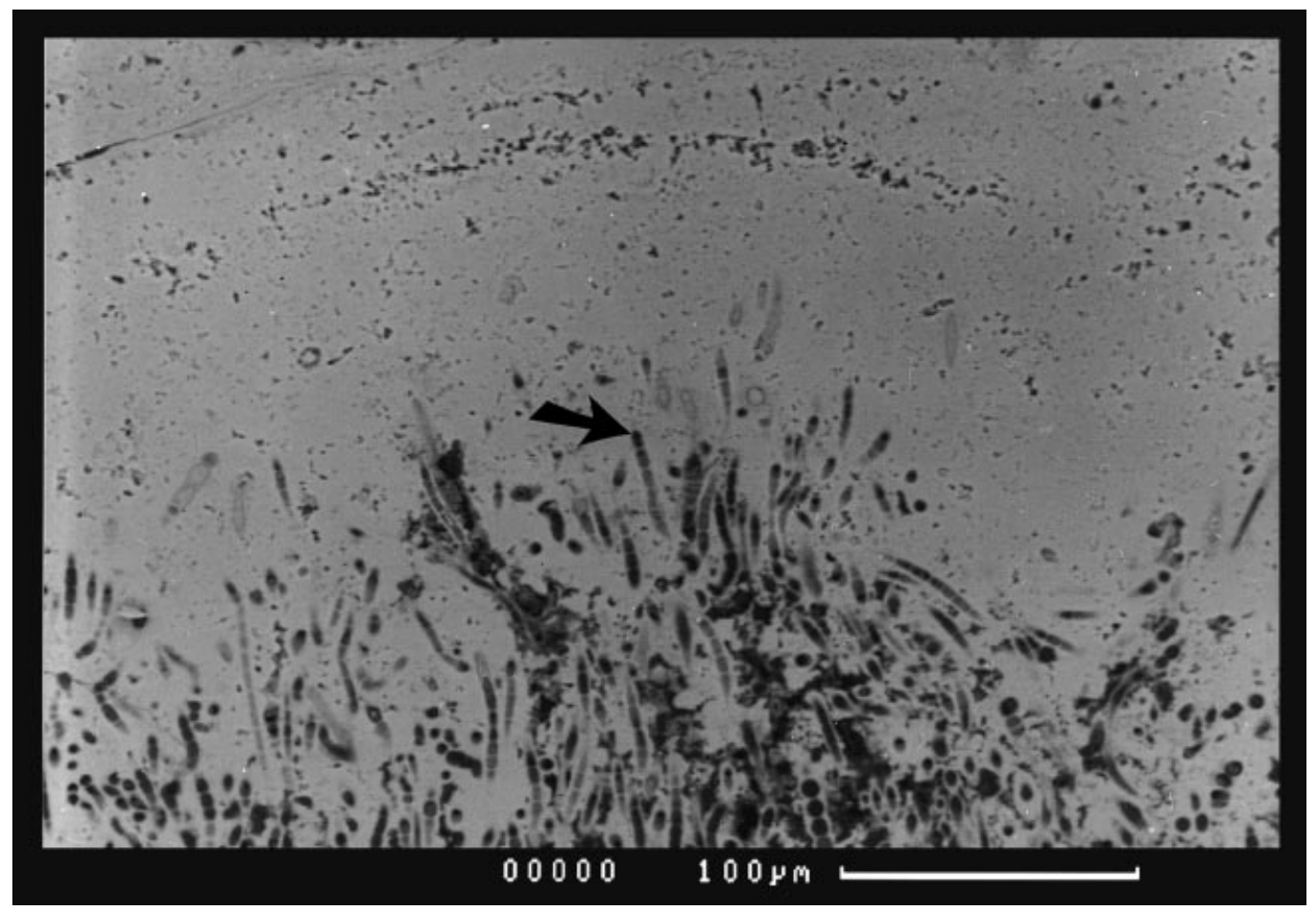

Fig. 4. Close-up SEM image from Fig. $2 \mathrm{E}$ of the gradational upper surface of the microbial layer. Note the preferred vertical orientation of the cyanobacterial cells towards the sediment-water interface and the isolated cyanobacterial filaments projecting into the silica layer above (arrow). There is no continuum between the microorganisms of one layer with those of an overlying microbial layer 100's of micrometres above.

sp. (Fig. 5B). Some of the microstromatolite microflora have subsequently been isolated and cultured, and it is suggested that the predominant cyanobacteria are indeed Calothrix sp. and Fischerella sp. This correlates well with studies at Yellowstone (Walter et al., 1972; Walter, 1976a; Cady \& Farmer, 1996); Ohaaki Pool and Dragon's Mouth Geyser (Jones et al., 1997a; 1998); Lake Bogoria (Renault et al., 1998); and Krisuvik (Castenholz, 1973), where low-temperature microstromatolites consist of similar microbial assemblages. Unidentified epiphytic bacterial cells also occur directly attached to the sheaths of Fischerella sp., a finding consistent with previous observations showing high abundances of bacteria associated with cyanobacterial exopolymers (Caldwell \& Caldwell, 1978; Cady \& Farmer, 1996).

The relatively limited distribution of species throughout the microstromatolite is expected under the extreme conditions of a hot spring, whereby a few dominant microorganisms dictate the system's overall structure (i.e. the filamentous fabric, Golubic, 1991). It cannot, however, be stated with certainty that filamentous bacteria (e.g. Chloroflexus sp.) are not associated with the microstromatolite, as had previously been reported in the spring waters at Krisuvik, where temperatures were between 45 and $56{ }^{\circ} \mathrm{C}$ (Castenholz, 1973). Under both the light microscope and SEM, especially when finer cellular features are lost as a result of silicification, cyanobacteria and Chloroflexus are morphologically similar (Walter et al., 1972; Schultze-Lam et al., 1995), and even under fluorescent microscopy, these microorganisms can be difficult to distinguish.

Almost all cyanobacteria analysed throughout the microstromatolite were encrusted in silica, the silicification occurring on the external sheaths of the microorganisms. Alternating horizons of light and more heavily mineralized microorganisms occur within the wedge (see C in Fig. 2). These layers of different intensity biomineralization grade into one another (Fig. 6). At the centre of the wedge, lightly silicified cyanobacteria are surrounded by dark amorphous material, presumably extracellular polysaccharides and lysed cells. It is interesting to note that in the more organic regions the cells have $<5 \mu \mathrm{m}$ silica coatings (Fig. 7A), while some cells in the more silicified regions are encrusted in a silica matrix tens of micrometres in thickness (Fig. 7B). It is likely that the biomineralization gradient reflects two different processes. First, when the micro- 


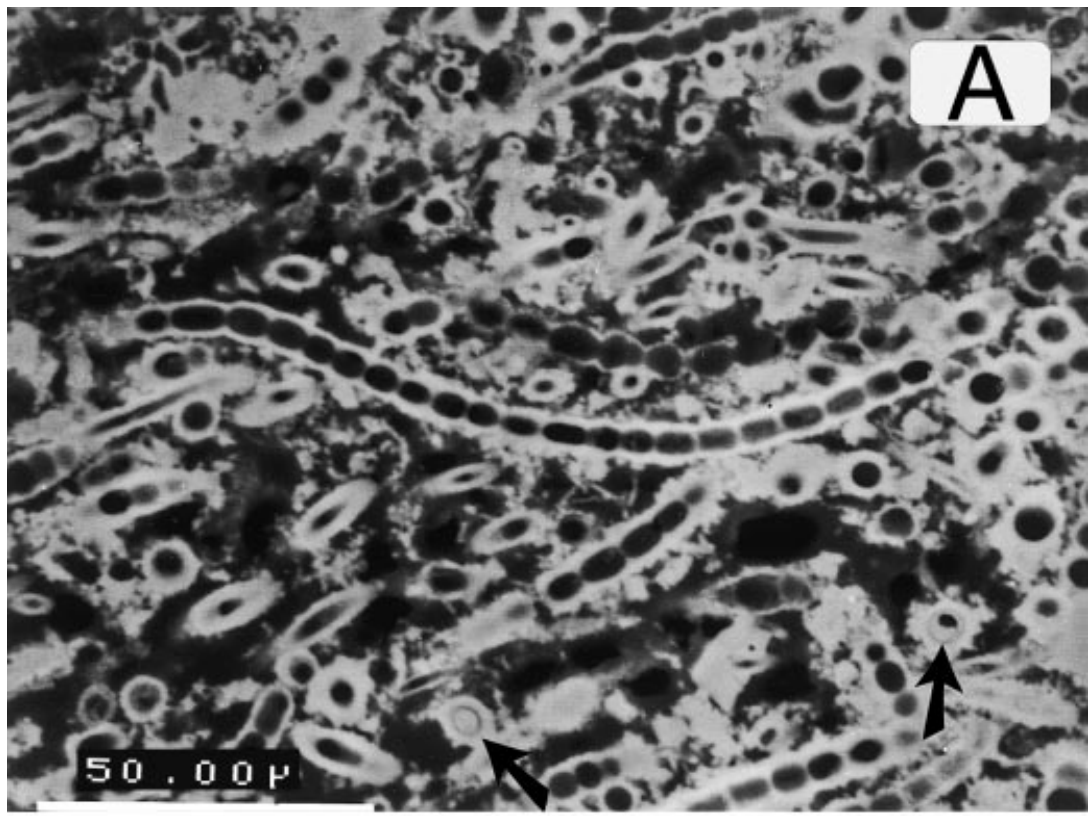

Fig. 5. SEM images of the dominant microorganisms growing within the microbial layers. (A) filamentous cyanobacteria, identified as Calothrix sp., with individual cells ranging in size from $5 \mu \mathrm{m}$ to $8 \mu \mathrm{m}$. (B) Other filamentous cells displaying lateral branching characteristic of Fischerella sp. Arrows in both figures indicate those lysed cells with intracellular silicification, selectively preserving the cell sheaths and walls.

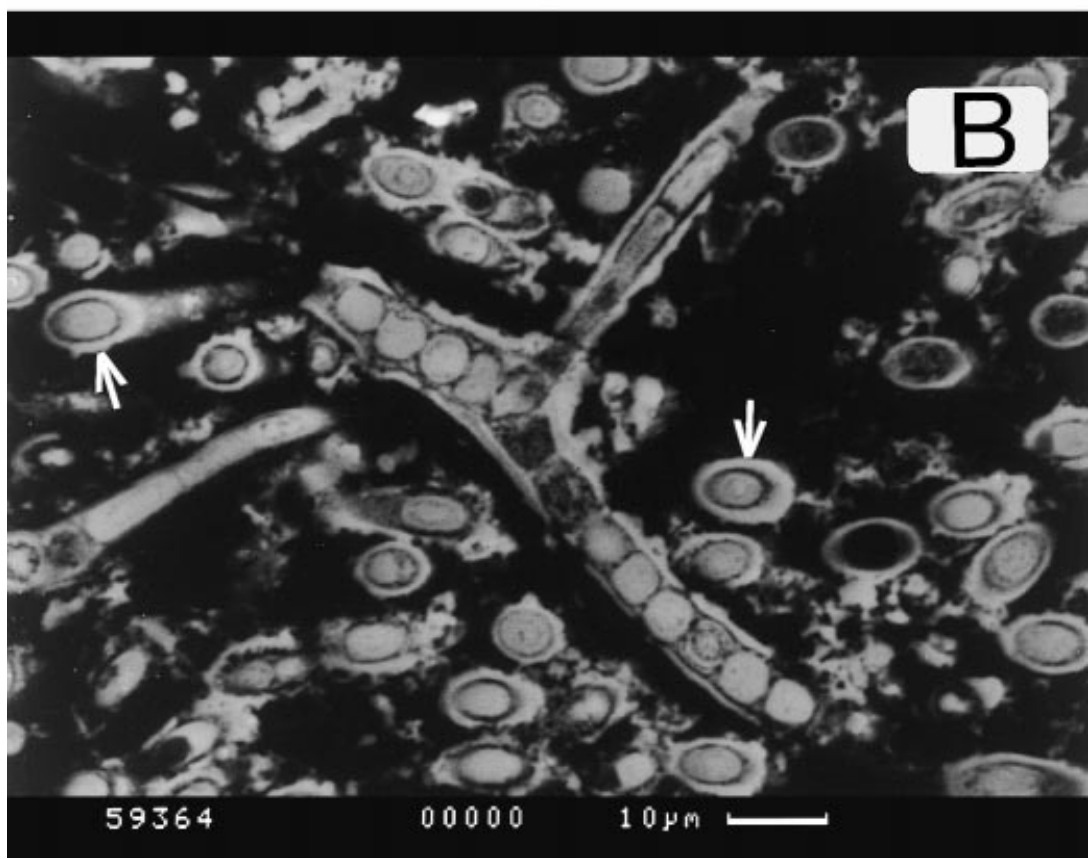

stromatolite was initially precipitated, the cells were silicified in situ (see discussion below). After accretion, those layers were effectively cut off from additional contact with the overlying fluids. Later fracturing, however, opened up the centre of the wedge, allowing additional fluids (and microorganisms) to move upwards into the available space. Because the interior cells are lightly mineralized, it is speculated that those later fluids were either not as silica saturated or there was a limited flux of soluble silica through the fracture, thereby limiting the extent of silicification observed elsewhere.
At the top of the wedge the colony spreads out laterally to form a more diffuse microbial horizon (see D in Fig. 2); the cyanobacteria in this horizon are more heavily mineralized than those in the colony. The top of the colony is also very gradational, with isolated cyanobacterial cells projecting into the silica layers above (see $\mathrm{E}$ in Fig. 2; Fig. 4). Directly above the bacterial colony (the overlying $500 \mathrm{~nm}$ ) the microstromatolite exclusively contains layers of weakly laminated silica (i.e. there is no evidence of cyanobacteria). For the next $4 \mathrm{~mm}$ of overlying deposit, the 'microbial' layers alternate with those of weakly 


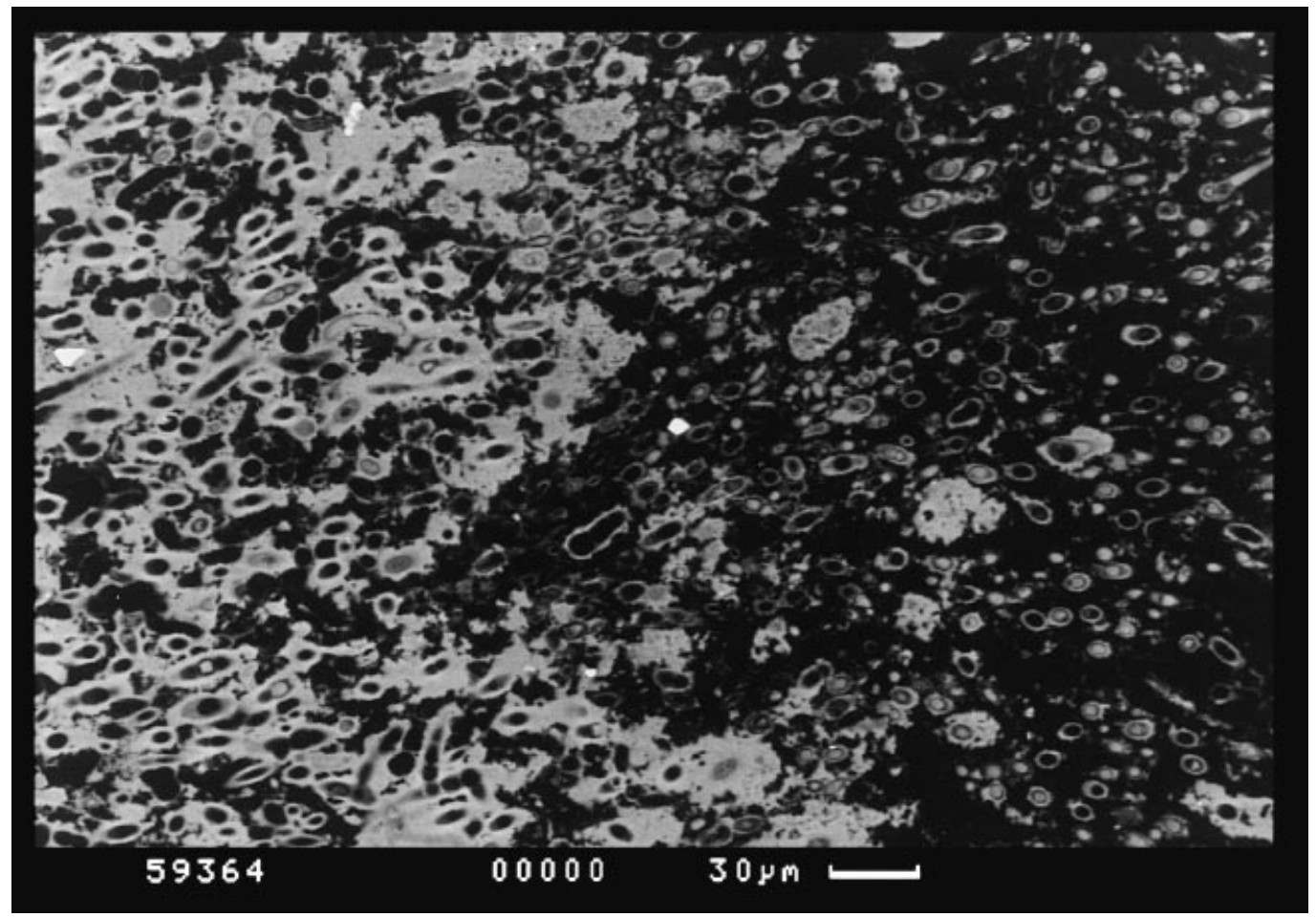

Fig. 6. Close-up SEM image from Fig. $2 \mathrm{C}$ within the microbial wedge where different intensities of biomineralization grade into one another. On the left, entire colonies of cyanobacterial cells are completely encrusted within a dense silica matrix (white colour), whereas on the right, most cells are only lightly silicified (i.e. silica crust on individual cells are $<5 \mu \mathrm{m}$ ) and are surrounded by amorphous organic material (dark colour).

laminated silica. The microbial layers, which vary from $50 \mu \mathrm{m}$ to $150 \mu \mathrm{m}$ in thickness, are often laterally connected to denser colonies which occur in dips in the microstromatolite (see $\mathrm{F}$ in Fig. 2). In those particular instances, the colonies have filled in the undulating topographical feature that probably existed at the time of colonization. Similar observations have been reported in Yellowstone (Cady \& Farmer, 1996). There, microbial communities were found growing within irregular depressions bounded by ridges where mat organisms had undergone various degrees of silicification. The topmost portion of the microstromatolite is composed of a very thin siliceous layer (10's of micrometres thick) directly above a microbial layer (see G in Fig. 2).

\section{MODERN MICROSTROMATOLITE FORMATION}

Detailed examination of the siliceous microstromatolite from Krisuvik, Iceland shows that almost all cyanobacteria observed under the SEM, both living and lysed, are silicified. Clearly a major component of the deposit's overall structure, nearly half its thickness, is attributed to biomineralization. The thickness of the silica matrix on cells varies in different horizons. In heavily mineralized regions, the silica matrix extends to encompass entire colonies of cells, while in lightly mineralized regions, only individual cells are silicified. This correlates well with previous experimental fossilization studies (Oehler \& Schopf, 1971; Oehler, 1976; Ferris et al., 1988; Westall et al., 1995) and electron microscopic analyses of siliceous sinter (Schultze-Lam et al., 1995; Cady \& Farmer, 1996; Konhauser \& Ferris, 1996; Jones et al., 1998; Konhauser et al., 1999) that documented microbial sheath and cell wall material serving as nucleation sites for the epicellular precipitation of silica-rich spheroidal grains and crusts. Ferris et al. (1988) have also shown the rapid development of silica precipitates on cellular debris after cell lysis. Evidently, lysed microorganisms continue to serve as templates for silica deposition, with cellular degradation enhancing mineralization by increasing the availability of functional groups capable of forming hydrogen bonds with dissolved silica (Knoll, 1985; Ferris et al., 1988). During sustained 


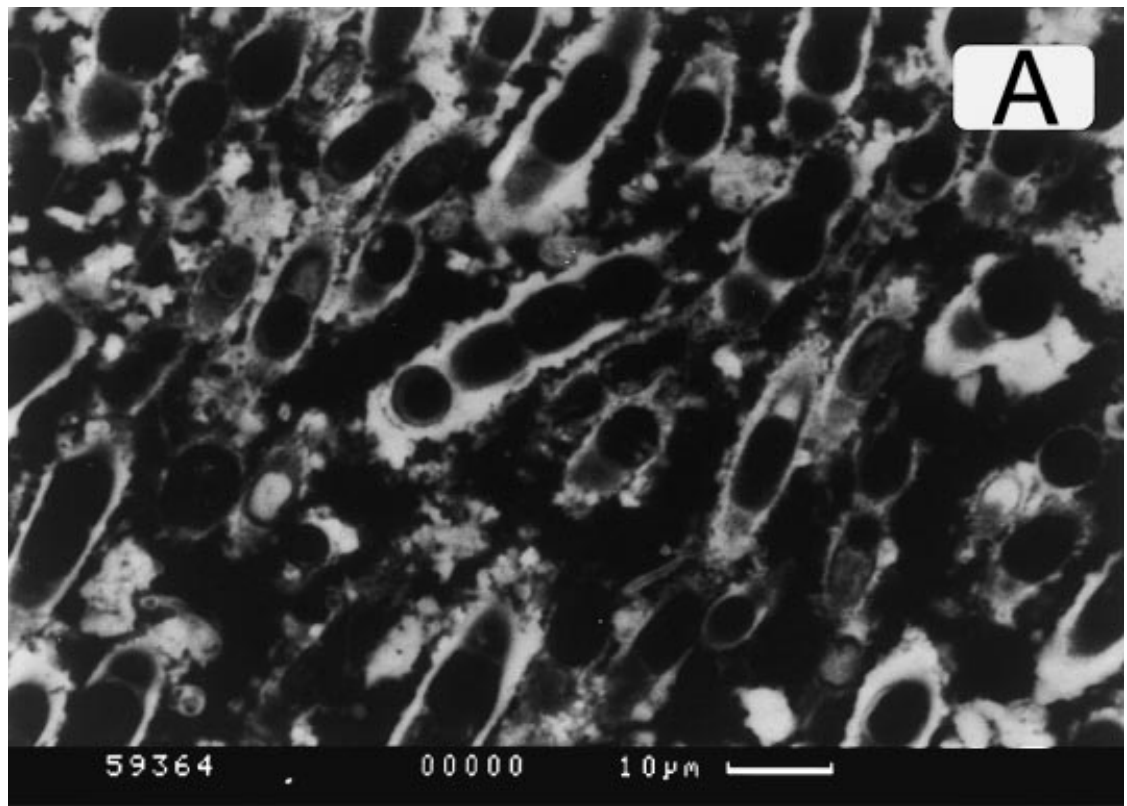

Fig. 7. Detailed SEM images of the different intensity biomineralization observed in Fig. 6. (A) Lightly silicified cyanobacteria $(<5 \mu \mathrm{m}$ thick silica crust) surrounded by dark amorphous organic material, presumably extracellular polysaccharides and lysed cells. Note how silicification occurs almost exclusively on the external sheaths of the microorganisms. Intracellular silicification is infrequently observed, suggesting that most cells were intact (and probably viable) at the time of sampling. (B) Cells in the more silicified horizons that are encrusted in a silica matrix tens of micrometres in thickness.

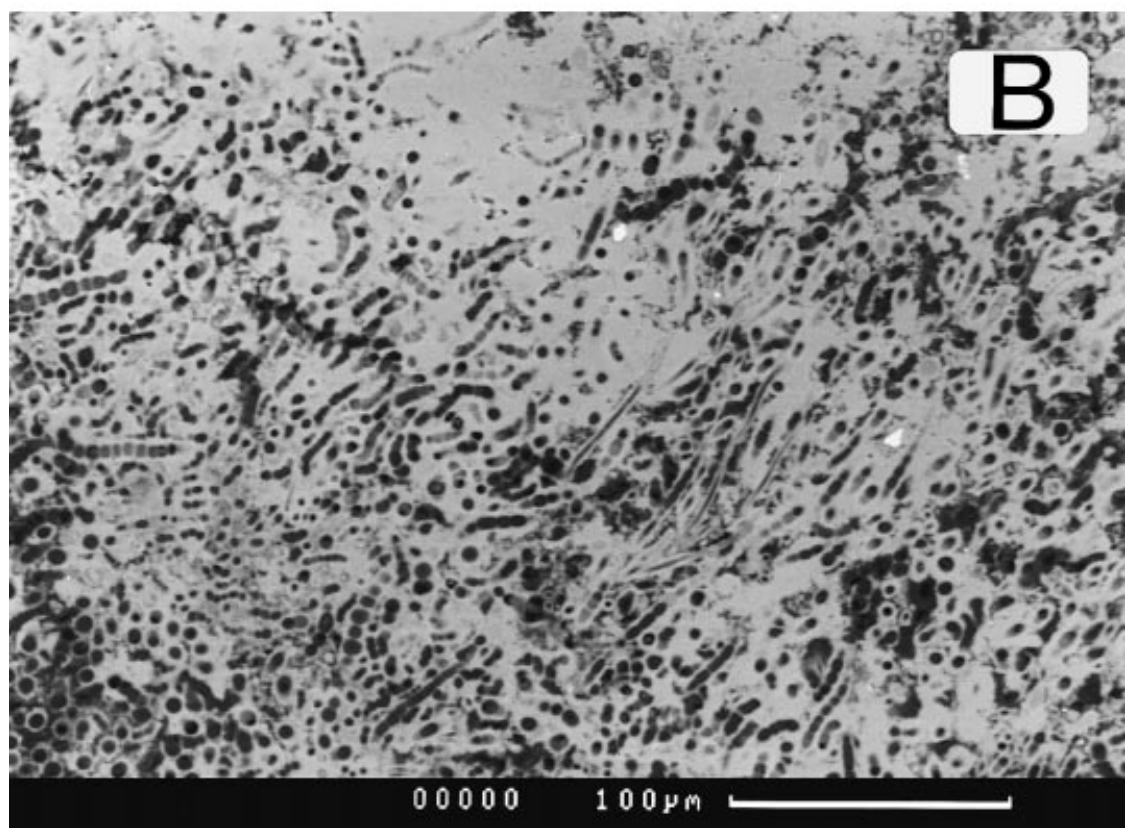

silicification, the silica crusts around bacteria thicken; the silica becomes more crystalline (i.e. less porous and more dense); and loosely aggregated spheres coalesce to form a botryoidal external crust to which other spheres become attached (Westall et al., 1995). Over time, and with an increased mass of solid silica on individual cells, entire colonies of cells become mineralized.

From the overall profile described above, it is also evident that two very distinct lamina types repeatedly occur throughout the microstromatolite: microbial layers are predominantly consist- ing of filamentous, intact, vertically aligned, silicified cyanobacteria; and weakly laminated silica layers which appear to be devoid of any microbial component. The microbial layers commonly have a sharply defined base, overlying the weakly laminated silica, and a gradational upper surface merging into the weakly laminated silica. Being derived from deep groundwaters, the hydrothermal water source to the springs is more-or-less constant (in terms of flow, temperature and chemistry) throughout the year (Arnorsson et al., 1975). Therefore, the cyclic laminations must be explained by variations in 
microbial activity. As studies on other modern stromatolites have shown, accretion by mineral precipitation forces an upward displacement of the entire microbial community. The microorganisms respond to encrustation by upward growth and/or movement, rapidly colonizing new surfaces to maintain their optimal growth positions in the sediment (Golubic, 1976). If this progression proceeds at an even rate, then the resulting stromatolite will appear uniform, with degradation removing the dead organic matter at the bottom. Only if a recurring disruption occurs in the process of accretion will laminae be preserved (Golubic, 1991). In the Icelandic microstromatolite, this disruption may be a seasonal growth pattern; a logical conclusion considering that the microorganisms are dominated by phototrophs that rely on sunlight for energy and Iceland, at a fairly high northern latitude, experiences large seasonal variations in the intensity of solar radiation. Furthermore, the limited distribution of cyanobacterial species indicates that the laminations are not the result of some competitive behaviour of different mat microorganisms, as commonly described in carbonate stromatolites (Monty, 1976; Gerdes et al., 1994; Seong-Joo et al., 2000). Instead, the microbial layers are simply due to the growth patterns of the predominant cyanobacteria, Calothrix sp.

The seasonality hypothesis is corroborated by observations on the thickness of the laminations, as well as some preliminary results on field silicification rates. Based on SEM analyses it is estimated that the average thickness of a pair of laminations (representing one year) is approximately $500 \mu \mathrm{m}$ : this value obviously varies in different localities around the vent. This contrasts significantly with microstromatolites forming under diurnal influence (e.g. Yellowstone), where the average lamination thickness is 10's of $\mu \mathrm{m}$ thick (Walter et al., 1972).

SEM analysis of the slides left for several days in Krisuvik revealed them to be covered in very irregular and globular amorphous silica precipitates. The silica did not evenly cover all slides, in places forming peaks up to 15 or $20 \mu \mathrm{m}$ thick, while in other areas of the slide exhibited no precipitates. However, on average, most slides were covered with precipitates on the order of 5$10 \mu \mathrm{m}$ thick. Using these values to estimate silica precipitation over a 1-year cycle, a silica deposition rate from between 0.45 and $0.9 \mathrm{~mm} \mathrm{year}^{-1}$ is estimated. This correlates well with SEM estimates and the rates of oncoid growth around Champagne Pool, where the average rate of silica precipitation was 0·2-0.65 $\mathrm{mm}$ year $^{-1}$ (Jones et al., 1999).

If each pair of laminations represents 1 year, then 25 pairs of alternating laminations should exist within the microstromatolite. However, there are only 10 microbial layers of significant thickness, and many of the layers are not consistent throughout the section, implying that: the microorganisms did not colonize the surface equally; some of the organic material has not been preserved; or silicification was not constant at any one location throughout the past 25 years. Observations of emergent sinter terraces, as well as friable and unconsolidated sinter which were precipitated in the past, implies that local hydraulic conditions have fluctuated. It is thus likely that microstromatolite formation also fluctuated between periods of submergence and emergence such that a continuous record of sinter accretion may not actually exist at any one point. The preferential association of microbial populations with topographically low features within the microstromatolite also seems to suggest that the microorganisms selectively colonized surfaces that were submerged, and perhaps afforded the microorganisms some measure of protection from fluid turbulence (Ferris et al., 1989). Therefore, when vertical accretion results in emergence, lateral growth (into the dips of the microstromatolite) may be a means by which some cells keep themselves submerged.

The vertical orientation of the cells within the wedge indicates a photoresponsive behaviour, and attests to their attempt to maintain an optimal position in the microstromatolite with regards to the surface. The filamentous structure of the cells shows that the cyanobacteria are growing upwards, yet their vertical orientation may not necessarily reflect their requirement to be nearer the surface. Instead, their alignment may represent an attempt to minimize direct exposure to sunlight, the cells being forced to grow upwards due to limited space laterally. Many cyanobacteria are harmed by exposure to high intensities of solar radiation and photosynthetically active sunlight, causing biochemical and structural damage to the cell (Vincent \& Roy, 1993; Quesada \& Vincent, 1997). To avoid such detrimental effects some species of cyanobacteria have the ability to reduce their exposure by vertical migration strategies, using gliding motility and some form of photoresponse to move upwards and downwards through a mat (Castenholz et al., 1991). Other cells may develop an endolithic mode of growth and bore into a lithified substrate 
to depths where light intensities are more suitable. Although this process is observed in carbonates, where cyanobacteria and heterotrophic bacteria occur to depths of a few millimetres (Pentecost, 1978; Ferris \& Lowson, 1997), the apparent lack of downward boring into the underlying silica layers seems to suggest that this substratum may be impenetrable. Data from non-silicified cyanobacterial mats has further demonstrated that cyanobacterial cells do not necessarily exhibit vertical mobility in response to changes in incident light. Instead, the cells may react by producing intracellular carotenoids (Paerl et al., 1983) or extracellular shielding pigments (Garcia-Pichel \& Castenholz, 1991); they may increase the actual density of the surface layers so that self-shading becomes effective deeper within the mat (Rambler \& Margulis, 1980); they may restore damaged cellular components by a variety of repair mechanisms (Vincent \& Roy, 1993); or the cells may reorient themselves in response to the intensity of solar radiation (Ramsing et al., 2000). In the latter instance, for example, cells positioned at 400-800 micrometres depth in a siliceous, laminated cyanobacterial mat (from Mushroom Spring, Yellowstone) formed vertically aligned stacks at noon when solar radiation was at its most intense. At other times in the day, the cells were randomly oriented throughout the mat. It was postulated that this vertical positioning behaviour reduced the crosssectional area of cells exposed to incident sunlight, thereby minimizing the photon load on its photosystems and avoiding damage due to excess light. Ramsing et al. (2000) further suggested that diel reorientation would be an energy-efficient alternative to vertical mass migration through a gelatinous-mineral matrix. Similar photoresponsive behaviour may explain the orientation of cyanobacterial cells in the Krisuvik microstromatolite, especially as both Calothrix and Fischerella are immotile (see below). During the early stages of silicification, when the microbial communities in the near surface were still not entirely cemented in place by silica, the cells may yet have had the ability to align themselves into a preferred vertical orientation. Then during the spring and summer seasons silicification between erect filaments may have impelled them to grow upwards to prevent complete burial.

Although only conjecture at this point, the gradational top surface of each microbial layer suggests that silica precipitation must have gradually exceeded the ability of the bacteria to compensate (i.e. grow upwards); this probably reflects natural slowing of growth during the darkening autumn/winter months of Iceland. At this stage, silicification presumably occurs abiogenically due to the increased surface area initially generated by the silicified cells and later, by the small silica precipitates themselves. Thus, the microbial colony is probably not essential to this later stage of microstromatolite formation. In turn, the well-defined base suggests rapid recolonization of the inorganic precipitate surface by freeliving bacteria in the effluent, once conditions for surface attachment became favourable (i.e. Spring). It is during this stage that biogenic silicification becomes the dominant process, whereby cell growth rates are high and they produce new surfaces as fast, or faster, than silica precipitates cover them.

Interestingly, Calothrix and Fischerella are immotile for most of their life cycles, but in response to environmental stimuli they can differentiate to form specialized, motile filaments known as hormogonia (Rippka et al., 1979). These transient structures can glide at rates of up to $0.03 \mu \mathrm{m} \mathrm{s}^{-1}$ (Whitton, 1987) and eventually develop back into mature trichomes, sometimes within a day (Shilo \& Fattom, 1984). Hormogonia were observed in the shallow waters overlying the sinter terraces (using a field light microscope) and would provide a rapid means for recolonization of fresh microstromatolite surfaces in the spring. Their source would probably be the underlying cyanobacterial layer (see G in Fig. 2), presuming that the hormogonia could migrate through the freshly precipitated hydrous silica layer above. Calothrix, and especially Fischerella, can also form akinetes (spores) which tend to develop in response to cold or lower light intensities (Rippka et al., 1979). The akinetes are resistant to cold and desiccation, and could provide an inoculum for spring growth.

In hot spring environments, where the hydrothermal effluent is commonly saturated with respect to amorphous silica, the primary impediment for phototrophic microorganisms would seem to be how to keep pace with continuous accretion. Detailed images from this study, and colleagues, have clearly shown that microbial cells become completely encrusted in a siliceous matrix. So, how then are they capable of surviving in such apparently inhospitable environments? The presence of hormogonia (and possibly akinetes) suggests that recolonization may be the mechanism by which the microbial layers are initiated (Golubic, 1976), but what then happens to the cells below the uppermost layers? Because 
the overlying silica layers are relatively resistant, and presumably the microorganisms are unable to escape and move through them once they are completely cemented (i.e. the silica layers are intact above a microbial layer with no evidence of upward boring), the cells must be fixed at a given level within the microstromatolite. Therefore, their vertical alignment at depth may simply represent a relic orientation from when they were nearer the surface.

One obvious problem of biomineralization and burial for phototrophic microorganisms would be their attainment of sufficient light. Green-brown layers of microorganisms have been observed living below the silica surface, implying that those deeper layers are still microbially active: the fact that cyanobacterial cells from within the sinter were able to be cultivated confirms this. Pierson (1994) showed that a 3-mm-thick layer of quartz sand transmitted $5 \%$ of visible and near infrared radiation. Furthermore, Pentecost (1978) has shown that many cyanobacteria exist at depths within sediment where light levels are restricted to just $1 \%$ of the surface intensity. The PAL transmittance data collected from the Krisuvik microstromatolite shows, in Sample A and Sample B, that light levels greater than 1\% surface intensity exist below $1.5 \mathrm{~mm}$, and some PAL still penetrates up to $2-3 \mathrm{~mm}$ depth (Table 1). The discrepancy between the transmittance data and the observation that viable cells exist below $3 \mathrm{~mm}$ can be explained in either of two ways. First, there is a certain amount of variability in light transmittance within different sections of microstromatolite, such that the depth of light penetration may be deeper in the section shown in Fig. 2 than in those sections cut for the light transmittance analyses. The variation in light transmittance through different samples is exemplified by the difference between samples $\mathrm{B}$ and C (Table 1). Sample B, a predominantly light grey microstromatolite, allows approximately 1020 times more PAL transmittance than sample C, which is significantly more dark grey in colour. This dark grey material notably reduces PAL transmittance, and as it is present to some extent in all the wafers; it probably reduces the PAL transmittance values of all samples. The concentration of iron may also significantly reduce PAL transmittance. For example, Table 2 shows reduced PAL transmittance through wafers of Lýsuhóll sinter (containing $7000 \mu \mathrm{g} \mathrm{g}^{-1} \mathrm{Fe}$ compared with $300 \mu \mathrm{g} \mathrm{g}^{-1} \mathrm{Fe}$ in the Krisuvik samples). Therefore, a 0·2-mm section of Lýsuhóll sinter (L1) allows only $3.08 \%$ PAL to penetrate,
Table 1. PAL (photosynthetically active light) transmittance data for wafers of siliceous microstromatolites from the Krisuvik hot spring.

\begin{tabular}{lrll}
\hline $\begin{array}{l}\text { Wafer } \\
\text { thickness } \\
\text { (in mm) }\end{array}$ & $\begin{array}{l}\text { Sample A } \\
\text { (in \% PAL) }\end{array}$ & $\begin{array}{l}\text { Sample B } \\
\text { (in \% PAL) }\end{array}$ & $\begin{array}{l}\text { Sample C } \\
\text { (in \% PAL) }\end{array}$ \\
\hline 0.00 & 100.00 & 100.00 & 100.00 \\
0.20 & $23.86(1.72)$ & - & - \\
0.50 & $9.66(0.41)$ & - & - \\
0.75 & $3.37(0.06)$ & $7.53(1.22)$ & $0.30(0.06)$ \\
1.00 & $5.15(0.15)$ & $3.42(1.53)$ & $0.04(0.01)$ \\
1.50 & $1.28(0.07)$ & - & - \\
2.00 & $0.30(0.03)$ & $0.56(0.08)$ & $0.02(0.01)$ \\
3.00 & $-\quad 0.25(0.02)$ & $0.03(0.02)$ \\
\hline
\end{tabular}

Note: values in brackets are standard deviations.

compared with $23 \cdot 86 \%$ PAL transmittance form Krisuvik sample A.

The second possibility is that although the levels may be below $1 \%$, there may still be sufficient light for cell maintenance: the ability to grow photoheterotrophically at low light intensities is common amongst both Fischerella and Calothrix strains (Rippka et al., 1979). Members of both genera are also capable of slow, chemoheterotrophic growth in the dark (Whitton, 1987). However, if chemoheterotrophic growth was occurring at depth, it presumably was not anaerobic (i.e. linked to sulphate reduction): no authigenic sulphide minerals were observed within the microstromatolite even though it contained $300 \mu \mathrm{g} \mathrm{g}^{-1}$ of iron and the hydrothermal effluent contained $72.5 \mu \mathrm{g} \mathrm{mL}{ }^{-1}$ of dissolved sulphate.

As the siliceous microstromatolite continues to accrete, the bottom layers will eventually become metabolically inactive. Some of the remaining organic matter will become degraded, aerobically at first, and later by fermentation and anaerobic respiration. Organic matter associated with silicified cellular remains, however, may remain intact due to their early lithification.

Table 2. PAL transmittance data for wafers of sinterfrom the Lýsuhóll hot spring.

\begin{tabular}{lcc}
\hline $\begin{array}{l}\text { Wafer thickness } \\
\text { (in mm) }\end{array}$ & $\begin{array}{l}\text { Sinter L1 } \\
\text { (in \% PAL) }\end{array}$ & $\begin{array}{l}\text { Sinter L2 } \\
\text { (in \% PAL) }\end{array}$ \\
\hline 0.00 & $100 \cdot 00$ & $100 \cdot 00$ \\
$0 \cdot 15$ & $4 \cdot 44(0 \cdot 15)$ & $7 \cdot 40(0 \cdot 33)$ \\
$0 \cdot 20$ & $3 \cdot 08(0 \cdot 15)$ & $5 \cdot 44(0 \cdot 45)$ \\
$0 \cdot 25$ & $0.93(0 \cdot 15)$ & $1 \cdot 01(0 \cdot 06)$
\end{tabular}

Note: values in brackets are standard deviations. 


\section{IMPLICATIONS FOR PRECAMBRIAN STROMATOLITES}

This study has shown that in the siliceous, hot spring system at Krisuvik: (i) cyanobacteria contribute to silicification by providing reactive substrates for mineral formation; (ii) microbial silicification is rapid, as evident from the integrity and preservation of the mineralized cellular structures; (iii) the microstromatolites are laminated, with the cyclicity probably related to seasonal variations in microbial activity; (iv) recolonization of the solid silica surface occurs by free-living bacteria: cell motility is not responsible for the laminations; (v) microbial populations within the microstromatolite, some several $\mathrm{mm}$ in depth, are viable, even though mineralized; and (vi) photosynthetically active light (PAL) only transmits through the uppermost sinter layers, suggesting that 'deeper' microbial populations must differ metabolically or physiologically. Although variations in effluent composition, temperature (and hence microbial assemblages and biofacies) and climate will influence the patterns of sinter formation at other hot springs, this study unequivocally illustrates that modern sinter formation is intimately linked to microbial activity and that the sinter fabric results from a combination of biomineralization, cell growth and recolonization. In addition, the biogeochemical processes occurring at Krisuvik are of direct relevance to understanding the formation of other intimately layered, microcrystalline, siliceous sediments found in the geological rock record, e.g. stromatolitic iron formations and other Precambrian siliceous stromatolites. Certainly, early work in Yellowstone drew attention to the possibility of interpreting some distinctive ancient stromatolite morphologies from modern hot spring analogues (e.g. Walter, 1972, 1976b; Walter et al., 1972, 1992; Doemel \& Brock, 1974; 1977). This Icelandic study similarly provides potential analogues to those conditions under which some ancient microbial mats became initially silicified.

Precambrian stromatolites, and their recognizable microfossils, represent some of the earliest records of life on Earth and provide a proxy for the biogeochemical conditions of the early biosphere. Stromatolites are organosedimentary structures produced by sediment trapping, binding and/or precipitation activity of microorganisms, principally cyanobacteria (Awramik, 1992). These biogenic sedimentary structures have vertical relief from microscopic to reefs hundreds of metres high, and can extend laterally for hundreds of kilometres (Walter, 1994). One of the characteristic features of stromatolites, including the oldest examples of the Archean, is their lamination; ranging from wavy stratiform shapes, domes to columns, possessing laminae with thickness greater than $10 \mu \mathrm{m}$, and showing gradational boundaries between dark and light laminae (Awramik, 1992; Schopf, 1992, 1994; Walter, 1994). The laminations formed from a complex combination of environmental factors and behavioural responses of the microorganisms, which grew as layered ecosystems in environments subject to continuous sedimentation. The stromatolite structure thus became a cumulative record of an upwardly displaced microbial community over time.

Stromatolites from the $3.4 \mathrm{Ga}$ Warrawoona Group, Western Australia (Lowe, 1980) and the 3.3 Ga Fig Tree Group, South Africa (Byerly et al., 1986) occur in various chert units, some of which are considered primary in origin (Walter et al., 1980; Lowe, 1983; Walsh \& Lowe, 1985; Schopf \& Packer, 1987; Sugitani, 1992; Schopf, 1993). By the early Proterozoic (e.g. the $2 \cdot 0$ Ga Gunflint Iron Formation), there is clear evidence that microorganisms were preserved as microfossils in primary stromatolitic chert (Cloud, 1965). Other Precambrian stromatolites initially formed by processes of carbonate accretion, with the cherts representing a secondary mineral phase formed during early diagenesis (Buick \& Dunlop, 1990; Grotzinger, 1994). The actual role of cyanobacteria and/or bacteria in Precambrian carbonate precipitation remains undetermined (Riding, 1994), but based on modern laminated/clotted carbonate deposits, i.e. tufas, travertines, stromatolites and thrombolites, it seems likely that microorganisms were in some way directly involved in their formation (Burne \& Moore, 1987). In such modern biosedimentary structures, microbial populations become encrusted in authigenic carbonate minerals, a process induced by photosynthesis, organic decay and/or the concentration of calcium to microbial exopolymers (Krumbein, 1979; Pentecost \& Riding, 1986; Thompson \& Ferris, 1990; Chafetz et al., 1991; Golubic, 1991; Chafetz \& Buczynski, 1992; Gerdes et al., 1994; Feldman \& McKenzie, 1998). The microbial community thus catalyses carbonate cementation, with the newly accreted surfaces serving as further substrates for continued cellular growth. A combination of seasonal variations in precipitation, due to changes in water chemistry or microbial growth, and/or the movement of the cells out of the sediment subsequently gives 
rise to the laminations. Thus, it appears that silica and carbonate biomineralization in stromatolites are reasonably comparable processes.

Microfossils obtained from Archean stromatolites, comprising the remains of cell sheath and wall material preserved in a chert matrix (Knoll, 1985; Horodyski et al., 1992), appear to indicate that those microbes were similar to modern phototrophic, mat-forming microorganisms (Awramik, 1992; McNamara \& Awramik, 1992; Schopf, 1992, 1994). The presence of empty tubular sheaths and partitioned filaments resembling trichomes, which together with the common orientation of these microfossils parallel to the stromatolitic laminations, suggest that the microorganisms may have been capable of gliding, possibly phototactic motility (Awramik et al., 1983). Additionally, large-diameter coccoids enclosed in a multilamellated sheath, resembling modern-day cyanobacteria, suggest that some microbes were potentially oxygen producing (Schopf \& Packer, 1987; Schopf, 1993). Anoxygenic phototrophs, such as Chloroflexus sp., may also have been widespread during the Archean (Walter et al., 1972, 1980).

Results from this study contribute to the understanding of Precambrian siliceous stromatolites in two ways: (i) laminations in modern hot spring microstromatolites directly result from microbialsilica interactions; and (ii) microbes within the microstromatolite are fixed within certain horizons and do not need to be motile to survive, even after burial. In Icelandic microstromatolites, the overall structure consists of alternating layers of cyanobacteria and inorganic silica in an overall domical to columnar structure. In the growing season, cells contribute to silicification by serving as direct physico-chemical sites for mineral formation. Their growth rates are high relative to rates of silica deposition, and as they grow upwards to prevent complete burial, they continuously provide new nucleation sites for silicification. In the non-growing seasons, the silicification process is abiogenic, but probably uses either the pre-existing colonies or biogenic silica spheres as nucleation sites to reduce kinetic barriers. Therefore, it appears that nucleation of new silica precipitates is not a rate-limited step (Hinman \& Lindstrom, 1996), and that the laminations simply arise from the growth patterns of a limited cyanobacterial distribution, namely Calothrix sp., and to a lesser extent, Fischerella sp. Interestingly, experimentally based amorphous silica precipitation rates can be orders of magnitude slower than those observed in the field. This discrepancy has been attributed to surface defect and/or surface nucleation processes that arise in the field (Carroll et al., 1998). Because microorganisms are ubiquitous at hot springs, and microbial cell surfaces provide nucleation sites for silicification in modern systems, it is suggested that they may similarly have affected silica precipitation kinetics, and hence enhanced silicification in ancient siliceous deposits.

This study also seems to show that the silicification process encrusts cyanobacterial cells into a fixed position within a microbial layer. Apparently the silica layers are too hard for the Icelandic microorganisms to bore through because there is no visual evidence that the inorganic layers are in any way compromised by upward-moving microbes (i.e. the microbial layers are not vertically interconnected). Therefore, cell motility would seem to be a redundant feature to possess; instead the colonies rely on re-colonization of the solid surface when conditions become more suitable. Not surprisingly, both Calothrix and Fischerella are immotile for most of their life cycles. Furthermore, the observation that cells are still intact near the base of the microstromatolite suggests that burial beneath several layers of inorganic precipitates does not inhibit cell growth: instead, the cells may simply vary their mode of growth to compensate for the reduced availability of light. These patterns relate to the Archean as follows. Due to stratification of the Archean oceans, stromatolites were limited to shallow, aqueous environments where either upwelling or volcanic activity supplied nutrients (Awramik, 1992; Lowe, 1994). However, these were unstable sites, characterized by rapid fluctuations in water depth and subject to burial by lava, pyroclastic debris and a variety of detrital and biogenic sediments. For a benthic microbe to live at the sediment-water interface, where it required both light and nutrients in the overlying fluid, it needed to develop a strategy for coping with the dangers of burial by sediment or chemical precipitation, which ultimately led to the accretion of the stromatolite (Walter et al., 1980). Thus, the ability to be motile, and move (or grow) in the direction of accretion faster than the rate of sedimentation, appeared to be a prerequisite for survival (Awramik, 1992). However, if the findings in Iceland can be extended to those Archean mats, then silicified Archean microorganisms may not have found it necessary to be motile to survive, bringing into question the actual origins of the laminations in some ancient siliceous deposits. 


\section{ACKNOWLEDGEMENTS}

This work was supported by a Royal Society Research Grant to K.O.K. We gratefully appreciate and acknowledge the reviews by Grant Ferris, Malcolm Walter and Robert Riding.

\section{REFERENCES}

Arnorsson, S., Bjornsson, A., Grislason, G. and Gudmundsson, G. (1975) Systematic exploration of the Krisuvik high temperature area, Reykjanes Peninsula, Iceland. In: Second UN Symposium on the Development and Use of Geothermal Resources, pp. 853-864, San Francisco.

Awramik, S.M. (1992) The oldest records of photosynthesis. Photosynth. Res., 33, 75-89.

Awramik, S.M., Schopf, J.W. and Walter, M.R. (1983) Filamentous fossil bacteria from the Archean of Western Australia. Precambrian Res., 20, 357-374.

Bartley, J.K. (1996) Actualistic taphonomy of cyanobacteria: implications for the Precambrian fossil record. Palaios, 11, 571-586.

Buick, R. and Dunlop, J.S.R. (1990) Evaporitic sediments of early Archean age from the Warrawoona Group, North Pole, Western Australia. Sedimentology, 37, 247-277.

Burne, R.V. and Moore, L.S. (1987) Microbialites: organosedimentary deposits of benthic microbial communities. Palaios, 2, 241-254.

Byerly, G.R., Lowe, D.R. and Walsh, M.M. (1986) Stromatolites from the 3,300-3,500-Myr Swaziland Supergroup, Barberton Mountain Land, South Africa. Nature, 319, 489491.

Cady, S.L. and Farmer, J.D. (1996) Fossilization processes in siliceous thermal springs: trends in preservation along thermal gradients. In: Evolution of Hydrothermal Ecosystems on Earth (and Mars?) (Eds G.R. Brock and J.A. Goode), pp. 150-173. John Wiley, Chichester.

Caldwell, D.E. and Caldwell, S.J. (1978) Bacteriological characterization of phytoplankton cell surfaces. In: Environmental Biogeochemistry and Geomicrobiology (Ed. W.E. Krumbein), pp. 101-107. Ann. Arbor Science Publishers, Ann Arbor.

Carroll, S., Mroczek, E., Alai, M. and Ebert, M. (1998) Amorphous silica precipitation (60 to $\left.120^{\circ} \mathrm{C}\right)$ : comparison of laboratory and field rates. Geochim. Cosmochim. Acta, 62, 1379-1396.

Castenholz, R.W. (1973) The possible photosynthetic use of sulfide by the filamentous phototrophic bacteria of hot springs. Limnol. Oceanogr., 18, 863-876.

Castenholz, R.W., Jørgensen, B.B., D’Amelio, E. and Bauld, J. (1991) Photosynthetic and behavioral versatility of the cyanobacterium Oscillatoria boryana in a sulfide-rich microbial mat. FEMS Microbiol. Ecol., 86, 43-58.

Chafetz, H.S. and Buczynski, C. (1992) Bacterially induced lithification of microbial mats. Palaios, 7, 277-293.

Chafetz, H.S., Utech, N.M. and Fitzmaurice, S.P. (1991) Differences in the $\delta^{18} \mathrm{O}$ and $\delta^{13} \mathrm{C}$ signatures of seasonal laminae comprising travertine stromatolites. J. Sed. Petrol., 61, 1015-1028.

Cloud, P.E., Jr (1965) Significance of the Gunflint (Precambrian) microflora. Science, 148, 27-35.
Doemel, W.N. and Brock, T.D. (1974) Bacterial stromatolites: origin of laminations. Science, 184, 1083-1085.

Doemel, W.N. and Brock, T.D. (1977) Structure, growth, and decomposition of laminated algal-bacterial mats in alkaline hot springs. Appl. Environ. Microbiol., 34, 433-452.

Feldmann, M. and McKenzie, J.A. (1998) Stromatolitethrombolite associations in a modern environment, Lee Stocking Island, Bahamas. Palaios, 13, 201-212.

Ferris, F.G. and Lowson, E.A. (1997) Ultrastructure and geochemistry of endolithic microorganisms in limestone of the Niagara Escarpment. Can. J. Microbiol., 43, 211-219.

Ferris, F.G., Beveridge, T.J. and Fyfe, W.S. (1986) Iron-silica crystallite nucleation by bacteria in a geothermal sediment. Nature, 320, 609-611.

Ferris, F.G., Fyfe, W.S. and Beveridge, T.J. (1988) Metallic ion binding by Bacillus subtilis: implications for the fossilization of microorganisms. Geology, 16, 149-152.

Ferris, F.G., Fyfe, W.S., Witten, T., Schultze, S. and Beveridge, T.J. (1989) Effect of mineral substrate hardness on the population density of epilithic microorganisms in two Ontario rivers. Can. J. Microbiol., 35, 744-747.

Fournier, R.O. (1985) The behavior of silica in hydrothermal solutions. In: Geology and Geochemistry of Epithermal Systems (Eds B.R. Berger and P.M. Bethke), Soc. Econ. Geol., 2, 45-59.

Garcia-Pichel, F. and Castenholz, R.W. (1991) Characterization and biological implications of scytonemin, a cyanobacterial sheath pigment. J. Phycol., 27, 395-409.

Gerdes, G., Dunajtschik-Piewak, K., Riege, H., Taher, A.G., Krumbein, W.E. and Reineck, H.E. (1994) Structural diversity of biogenic carbonate particles in microbial mats. Sedimentology, 41, 1273-1294.

Golubic, S. (1976) Organisms that build stromatolites. In: Stromatolites: Developments in Sedimentology (Ed. M.R. Walter), pp. 113-126. Elsevier, Amsterdam.

Golubic, S. (1991) Modern stromatolites: a review. In: Calcareous Algae and Stromatolites (Ed. R. Riding), pp. 541-561. Springer-Verlag, Berlin.

Grotzinger, J.P. (1994) Trends in Precambrian carbonate sediments and their implication for understanding evolution. In: Early Life on Earth (Ed S. Bengtson), pp. 245-258. Columbia University Press, New York.

Hinman, N.W. and Lindstrom, R.F. (1996) Seasonal changes in silica deposition in hot spring systems. Chem. Geol., 132, 237-246.

Horodyski, R.J., Bauld, J., Lipps, J.H. and Mendelson, C.V. (1992) Preservation of prokaryotes and organic-walled and calcareous and siliceous protists. In: The Proterozoic Biosphere: a Multidisciplinary Study (Eds J.W. Schopf and C. Klein), pp. 185-193. Cambridge University Press, Cambridge.

Jones, B. and Renault, R.W. (1996) Influence of thermophilic bacteria on calcite and silica precipitation in hot springs with water temperatures above $90^{\circ} \mathrm{C}$ : evidence from Kenya and New Zealand. Can. J. Earth Sci., 33, 72-83.

Jones, B. and Renault, R.W. (1997) Formation of silica oncoids around geysers and hot springs at El Tatio, northern Chile. Sedimentology, 44, 287-304.

Jones, B., Renault, R.W. and Rosen, M.R. (1997a) Biogenicity of silica precipitation around geysers and hot-spring vents, North Island, New Zealand. J. Sed. Res., 67, 88-104.

Jones, B., Renault, R.W. and Rosen, M.R. (1997b) Vertical zonation of biota in microstromatolites associated with hot springs, North Island, New Zealand. Palaios, 12, 220-236. 
Jones, B., Renault, R.W. and Rosen, M.R. (1998) Microbial biofacies in hot-spring sinters: a model based on Ohaaki Pool, North Island, New Zealand. J. Sed. Res., 68, 413-434.

Jones, B., Renault, R.W. and Rosen, M.R. (1999) Actively growing siliceous oncoids in the Waiotapu geothermal area, North Island, New Zealand. J. Geol. Soc. London, 156, 89-103.

Knoll, A.H. (1985) Exceptional preservation of photosynthetic organisms in silicified carbonates and silicified peats. Phil. Trans. Roy. Soc. London, 311B, 111-122.

Konhauser, K.O. and Ferris, F.G. (1996) Diversity of iron and silica precipitation by microbial mats in hydrothermal waters, Iceland: implications for Precambrian iron formations. Geology, 24, 323-326.

Konhauser, K.O., Phoenix, V.R., Bottrell, S.H., Adams, D.G. and Head, I.M. (1999) Microbial-silica interactions in modern hot spring sinter. In: Geochemistry of the Earth's Surface (Ed. H. Ármannsson), pp. 263-266. Balkema, Rotterdam.

Krumbein, W.E. (1979) Photolithotrophic and chemoorganotrophic activity of bacteria and algae as related to beachrock formation and degradation (Gulf of Aqaba, Sinai). Geomicrobiol. J., 1, 139-203.

Lowe, D.R. (1980) Stromatolites 3,400-Myr old from the Archean of Western Australia. Nature, 284, 441-443.

Lowe, D.R. (1983) Restricted shallow-water sedimentation of early Archean stromatolitic and evaporitic strata of the Strelley Pool Chert, Pilbara Block, Western Australia. Precambrian Res., 19, 239-283.

Lowe, D.R. (1994) Early environments: constraints and opportunities for early evolution. In: Early Life on Earth (Ed. S. Bengtson), pp. 24-35. Columbia University Press, New York.

McNamara, K.J. and Awramik, S.M. (1992) Stromatolites: a key to understanding the early evolution of life. Sci. Prog., 76, 345-364.

Monty, C.L.V. (1976) The origin and development of cryptalgal fabrics. In: Stromatolites: Developments in Sedimentology (Ed. M.R. Walter), pp. 193-249. Elsevier, Amsterdam.

Oehler, J.H. (1976) Experimental studies in Precambrian paleontology: structural and chemical changes in blue-green algae during simulated fossilization in synthetic chert. Geol. Soc. Am. Bull., 87, 117-129.

Oehler, J.H. and Schopf, J.W. (1971) Artificial microfossils: experimental studies of permineralization of blue-green algae in silica. Science, 174, 1229-1231.

Paerl, H.W., Tucker, J. and Bland, P.T. (1983) Carotenoid enhancement and its role in maintaining blue-green algal (Microcystis aeruginosa) surface blooms. Limnol. Oceanogr., 28, 847-857.

Pentecost, A. (1978) Blue-green algae and freshwater carbonate deposits. Proc. Roy. Soc. London, 200B, 43-61.

Pentecost, A. and Riding, R. (1986) Calcification in cyanobacteria. In: Biomineralization in Lower Plants and Animals (Eds B.S.C. Leadbeater and R. Riding), pp. 73-90. Clarendon Press, Oxford.

Phoenix, V.R., Adams, D.G. and Konhauser, K.O. (2000) Cyanobacterial viability during hydrothermal biomineralisation. Chem. Geol., 169, 329-338.

Phoenix, V.R., Konhauser, K.O. and Adams, D.G. (1999) Photosynthetic controls on the silicification of cyanobacteria. In: Geochemistry of the Earth's Surface (Ed. H. Ármannsson), pp. 275-278. Balkema, Rotterdam.

Pierson, B.K. (1994) The emergence, diversification, and role of photosynthetic eubacteria. In: Early Life on Earth (Ed.
S. Bengtson), pp. 161-180. Columbia University Press, New York.

Quesada, A. and Vincent, W.F. (1997) Strategies of adaptation by Antarctic cyanobacteria to ultraviolet radiation. Eur. J. Phycol., 32, 335-342.

Rambler, M.B. and Margulis, L. (1980) Bacterial resistance to ultraviolet irradiation under anaerobiosis: implications for Pre-Phanerozoic evolution. Science, 210, 638-640.

Ramsing, N.B., Ferris, M.J. and Ward, D.M. (2000) Highly ordered vertical structure of Synechococcus populations within the one-millimeter-thick photic zone of a hot spring cyanobacterial mat. Appl. Environ. Microbiol., 66, 10381049.

Renault, R.W., Jones, B. and Rosen, M.R. (1996) Primary silica oncoids from Orakeikorako hot springs, North Island, New Zealand. Palaios, 11, 446-458.

Renault, R.W., Jones, B. and Tiercelin, J.J. (1998) Rapid in situ silicification of microbes at Loburu hot springs, Lake Bogoria, Kenya Rift Valley. Sedimentology, 45, 1083 1103.

Riding, R. (1994) Evolution of algal and cyanobacterial calcification. In: Early Life on Earth (Ed. S. Bengtson), pp. 426438. Columbia University Press, New York.

Rippka, R., Deruelles, J., Waterbury, J.B., Herdman, M. and Stanier, R.Y. (1979) Generic assignments, strain histories and properties of pure cultures of cyanobacteria. J. Gen. Microbiol., 111, 1-61.

Schopf, J.W. (1992) Paleobiology of the Archean. In: The Proterozoic Biosphere: a Multidisciplinary Study (Eds J.W. Schopf and C. Klein), pp. 25-39. Cambridge University Press, Cambridge.

Schopf, J.W. (1993) Microfossils of the early Archean Apex chert: new evidence of the antiquity of life. Science, $\mathbf{2 6 0}$, 640-646.

Schopf, J.W. (1994) The oldest known records of life: early Archean stromatolites, microfossils, and organic matter. In: Early Life on Earth (Ed. S. Bengtson), pp. 193-206. Columbia University Press, New York.

Schopf, J.W. and Packer, B.M. (1987) Early Archean (3.3-billion to 3.5-billion-year-old) microfossils from Warrawoona Group, Australia. Science, 237, 70-72.

Schultze-Lam, S., Ferris, F.G., Konhauser, K.O. and Wiese, R.G. (1995) In situ silicification of an Icelandic hot spring microbial mat: implications for microfossil formation. Can. J. Earth Sci., 32, 2021-2026.

Seong-Joo, L., Browne, K.M. and Golubic, S. (2000) On stromatolite lamination. In: Microbial Sediments (Eds. R.E. Riding and S.M. Awramik), pp. 16-24. Springer-Verlag, Heidelberg.

Shilo, M. and Fattom, A. (1984) The ecology and adaptive strategies of benthic cyanobacteria. In: Aspects of Microbial Metabolism and Ecology (Ed. G.A. Codd), pp. 175-186. Academic Press, New York.

Steefel, C.I. and Van Cappellen, P. (1990) A new kinetic approach to modeling water-rock interaction: the role of nucleation, precursors, and Ostwald ripening. Geochim. Cosmochim. Acta, 54, 2657-2677.

Sugitani, K. (1992) Geochemical characteristics of Archean cherts and other sedimentary rocks of the Pilbara Block, Western Australia: evidence for Archean seawater enriched in hydrothermally-derived iron and silica. Precambrian Res., 57, 21-47.

Thompson, J.B. and Ferris, F.G. (1990) Cyanobacterial precipitation of gypsum, calcite, and magnesite from natural alkaline lake water. Geology, 18, 995-998. 
Vincent, W.F. and Roy, S. (1993) Solar ultraviolet-B radiation and aquatic primary production: damage, protection, and recovery. Environ. Rev., 1, 1-12.

Walsh, M.M. and Lowe, D.R. (1985) Filamentous microfossils from 3,500-Myr-old Onverwacht Group, Barberton Mountain Land, South Africa. Nature, 314, 530-532.

Walter, M.R. (1972) A hot spring analog for the depositional environment of Precambrian iron formations of the Lake Superior Region. Econ. Geol., 67, 965-980.

Walter, M.R. (1976a) Hot-spring sediments in Yellowstone National Park. In: Stromatolites (Ed. M.R. Walter), pp. 489498. Elsevier, Amsterdam.

Walter, M.R. (1976b) Geyserites of Yellowstone National Park: an example of abiogenic 'stromatolites'. In: Stromatolites (Ed. M.R. Walter), pp. 88-112. Elsevier, Amsterdam.

Walter, M.R. (1994) Stromatolites: the main geological source of information on the evolution of the early benthos. In: Early Life on Earth (Ed. S. Bengtson), pp. 270-286. Columbia University Press, New York.

Walter, M.R., Bauld, J. and Brock, T.D. (1972) Siliceous algal and bacterial stromatolites in hot spring and geyser effluents of Yellowstone National Park. Science, 178, 402-405.
Walter, M.R., Bauld, J., Des Marais, D.J. and Schopf, J.W. (1992) A general comparison of microbial mats and microbial stromatolites: bridging the gap between the modern and the fossil. In: The Proterozoic Biosphere: a Multidisciplinary Study (Eds J.W. Schopf and C. Klein), pp. 335-338. Cambridge University Press, Cambridge.

Walter, M.R., Buick, R. and Dunlop, J.S.R. (1980) Stromatolites 3,400-3,500 Myr old from the North Pole area, Western Australia. Nature, 284, 443-445.

Westall, F., Boni, L. and Guerzoni, E. (1995) The experimental silicification of microorganisms. Palaeontology, 38, 495-528.

Whitton, B.A. (1987) The biology of Rivulariaceae. In: The Cyanobacteria - a Comparative Review (Eds P. Fay and C. van Baalen), pp. 513-534. Elsevier, Amsterdam.

Manuscript received 8 October 1999; revision accepted 17 August 2000. 